\title{
Dismissal Procedures in Albania: A Comparative Study
}

\author{
Artan Çela, PhD Candidate \\ University of Tirana, Faculty of Law, Head of Legal Representation, Department of Legal Affairs, Albanian Power Corporation \\ Email:artancela@gmail.com
}

\section{Doi:10.5901/mjss.2015.v6n2p95}

\begin{abstract}
Because of its economic and social implications, and in spite of regulation at the highest level, the termination of employment by the employer is one of the most sensitive issues in labour law today1. This article deal with the legal provisions concerning the termination of contract of employment by the employer, covering topics such as, the procedure of employment contract termination, notice to terminate the contract of employment, damages or compensation for unfair or unjustified dismissal. It offers a comparative overview of the procedures governing termination of employment in Albania and some industrialized countries of EU Member States. In Albania, this article deals only with employees whose work is regulated by the labour code, categories of employed persons whose terms and conditions of employment are governed by specific law, are beyond the scope of this Article.
\end{abstract}

Keywords: dismissal; termination of employment; laying off; period of notice; compensation for dismissal;

\section{Introduction}

The traditional rules governing the contract of employment which developed in various countries during the nineteenth century were characterized by a formal symmetry of the rights of either party to terminate the contract of employment, by giving notice, without either party having to justify its decision. However, the consequences of this equivalency of rights differed widely for the parties: termination of the contract by the worker - exercising his fundamental right to protect his freedom of work - is in most cases merely inconvenience for the employer, whilst the termination of the contract of employment by the employer could result in insecurity and poverty for the worker and his family, particularly during periods of massive unemployment ${ }^{2}$. For this reason the objective of this article is to provide an overview in termination of employment by employer in Albania and some EU Member States including information in dismissal procedural, period of notice and damages or compensation for unfair or unjustified dismissal. The countries, France, Germany and United Kingdom have been selected to provide a diversity of systems, in geographic, developmental and legal terms. It provides an introductory summary of the legislation on termination of employment by employer. This article is divided into six parts, including this introduction and concluding remarks.

\section{Termination of Employment by the Employer}

An employees right not to be unfairly or unjustifiably dismissed is a modern cornerstone of the law relating to the termination of employment. The ILO first began examining the question of international standards on termination of contracts of employment more than 60 years ago ${ }^{3}$. Under Article 3 of ILO Convention No.158 (1982), the terms "termination" and "termination of employment" mean termination of employment at the initiative of the employer. Article 4 of the Convention provides that "the employment of a worker shall not be terminated unless there is a valid reason for such termination". Article 5 of the Convention lists a number of reasons that do not constitute valid reasons for termination of employment. The need to base termination of employment on a valid reason is the cornerstone of the Convention's provisions. The adoption of this principle removes the possibility for the employer to unilaterally end an employment relationship of indeterminate duration by means of a period of notice or compensation in lieu thereof. The Convention requires that there be a valid reason for termination of employment, whether it is terminated following a period of notice or not. In other words, giving the worker a period of notice does not exempt the employer from stating his

\footnotetext{
1 International Labour Organization (2000). Terminations of employment digest: A legislative review. International Labour Office. Geneva, pp.7.

2 International Labour Conference 82 Session 1995 (1995). Protection against Unjustified Dismissal. International Labour Office. Geneva, pp. 1.

3 International Labour Organization, International Labour Standards Department (2011). Termination of Employment Instruments. Geneva.
} 
reasons or terminating the employment. National laws and practices that only require a valid reason for termination of employment where there is not period of notice (this is generally in the case of serious misconduct) and that do not require justification for termination of employment when notice has been given are not in accordance with the Convention 4 .

In Albania, according to Article 141 of the Code of Labor, the contract of undefined duration will end, if one of the parties terminates it, or if the notice deadline expires. At any time the employer may immediately terminate the contract for reasonable causes. Reasonable cause will be considered all the serious circumstances that, in accordance of the principle of mutual trust, do not allow for asking the employer to continue the labor relations. The court decides itself whether there have been reasonable causes for the immediate termination of the contract. Reasonable causes will be considered only those cases where the employee violates the contractual obligations of serious offence, as well as the cases where the employee repeatedly violates the contractual obligations of non-serious offence, regardless of the employer's written warning. If the contract is terminated for no reasonable cause, then the employee will have the right to sue the employer at the court within 180 days, starting from the day on which the notice deadline has expired. (See Article 146 of CL). At any time the employer may immediately terminate the contract for reasonable causes. Furthermore, the employer may not terminate the contract in the case where, according to the legislation in force, the employee is completing his/her military service, benefits payment related to temporary disability to work from the employer or Social Insurance for a period of not longer than one than one years, as well as in the case where the employee is one vocations given to him/her by the employer ${ }^{5}$.

In France, the Labour Code states that all dismissal should be based on well-founded an valid grounds. In the absence of agreement between the parties, a contract of employment may be terminated by the employer only on account of serious misconduct or in the case of force majeure. A contract of employment for an unspecified period may be terminated by either of the parties. The termination by an employer should be justified by a genuine and serious reason. Any termination carried out by an employer for one or more reasons not inherent in the personality of the employee resulting from the elimination or transformation of the job or a substantial modification of the contract of employment, especially after economic hardships or technological changes, constitutes a dismissal for economic reasons. No employer may terminate the contract of a woman who has been medically certified as pregnant; nor may her employment be terminated during a period of leave to which she is entitled (whether or not she takes it), or within four weeks of the expiration of the leave period. In addition, an employer may not terminate the employment of a worker whose contract has been suspended because of an employment injury or occupational disease, unless the employer can show that the employee has engaged in serious misconduct or that it is impossible, for reasons unrelated to the injury or illness, or the contract to continue in force. Termination of the employment of a trade union delegate, an employee representative and persons of similar status can only occur after authorization by the labour inspectorate. Sec. L.122-45 of the Labour Code states that no dismissal may be founded on discrimination based upon origin, sex, family status, race, nationality, political opinion, trade union activities, religion, disability, or exercise of the right to strike or health. Any such dismissal is considered null and void.

In Germany, pursuant to sec.626 of the Civil Code, the reasons for summary dismissal must be based on grave misconduct or incompetence of the employee, or severe economic circumstances to the behaviour of the employee. However, the dismissal is only lawful if in view of all circumstances of the case, and in evaluating the interest of both parties, it is intolerable for either of the parties to fulfil the contract until the period of notice. Examples of serious breaches of contract include a criminal offence, persistent refusal to fulfil the contract of employment in spite of warnings, and deceiving the employer about skills or qualifications essential for the job. White Collar Employees Act also lists additional grounds for summary dismissal. Summary dismissal must be carried out with two weeks of the occurrence on which it is based. The Protection Against Dismissal Act, prima facie position on dismissal is that it is assumed to be socially unjustifiable and therefore unlawful. The first and foremost aim of the PADA is to protect the employees contract of employment. The PADA define collective redundancy as a situation where, within a given period of 30 days, the employment relationship of a relatively large number of employees is actually terminated by the employer by way or ordinary dismissal with notice.

In United Kingdom, according to the common law, any contract may be terminated by either party with due notice. However, the common law has been restricted by legislation aimed at curbing unfair dismissal. The Employment Rights Act (1996) includes, as a principle, the right of an employee not to be dismissed unfairly. According to sec.98 of the Employment Rights Act, a dismissal may be fair if the employer shows that the reason or the principal reason for the

\footnotetext{
${ }^{4}$ International Labour Conference 82 Session 1995 (1995). Protection against Unjustified Dismissal. International Labour Office. Geneva, pp.7.

${ }^{5}$ Law No.7961, dated 12.07.1995 Code of Labor of the Republic of Albania
} 
dismissal is contained in sec.98 (2) of that Act. (The employee has the initial evidentiary burden of proving a dismissal has taken place, then the burden of showing cause shifts to the employer). Where the employer has fulfilled this requirement, it rest with the Industrial Tribunal to decide whether in all circumstances the employer acted as a reasonable employer in dismissing the employee ${ }^{6}$.

\section{Procedures for Dismissal}

An effective system of protection against unjustified termination of employment must include not only a requirement that dismissals must be based on valid reasons, but procedures to ensure compliance with this requirement. These procedures can be divided into two categories: those to be observed before or at the time of termination and those governing appeals against termination including compensation if it is found that there was no valid reason or termination of employment? ${ }^{7}$.

The Code of Labor of the Republic of Albania provides that after the probation period, when the employer thinks to terminate the contract of employment, he/she must inform the employee in writing at least 72 hours before the meeting, and talk with him/her. The employer, during the conversation, shall present to the employee the reasons concerning the decision planned to be taken, and offer him/her the opportunity to express himself/herself. The termination of the contract shall be made known to the employee within a time limit of 48 hours up to one week after the appointment. This procedure shall be applied even in the case of an immediate termination of the contract. This provision does not apply to the cases of collective dismissals from work (see Article 143 of Code of Labour).

When the employer plans to execute collective dismissals ${ }^{8}$ from work, he/she is obliged to inform in writing the employees organization recognized as the representative of the employees. In absence of this, the employer informs his/her employee through advertisements put on the workplace, which can be easily seen. The notice must contain especially the reasons of dismissal from work, the number of the employees to be dismissed, the number of the employee normally employed, as well as the time during which it is planned to execute these dismissals. The employer submits to the Ministry of Labor and Social Affairs a copy of this notice. The employer makes consultations with the employees organization, recognized as the representative of the employees, for the purpose of reaching an agreement. In absence of this, the employer gives the opportunity to the employees to participate in the consultations. They are made in order to take measures to avoid or reduce the collective dismissals from work and to soften their consequences. The consultations are made within 20 days, starting on the day of notice, except for the case where the employer accepts a long duration. The employer informs in writing the Ministry of Labor and Social Affairs concerning the completion of the consultations. He/she sends a copy of this notice to the concerned party. If the parties have failed to agree, the Ministry of Labor and Social Affairs helps them to reach an agreement within 20 days, starting from the day of notice, except for the case where the employer accepts a longer duration. The Ministry of Labor and Social Affairs can by no means stop the collective dismissals from work. After the termination of the twenty-day deadline the employer informs the employees to be dismissed about the termination of the contract, respecting the notice deadlines as defined by Article $143^{9}$.

In France, an employer who proposes to dismiss an employee must, before making a decision, summon the person concerned, stating the purpose of the summons. Employees may be accompanied at the interview by an advisor of their choice. During the interview, the employer must give the reason for the proposed decision and hear the employees' explanations. The decision to carry out the dismissal must be transmitted by registered letter and the employer must specify therein the reason or reasons for the dismissal. An employer who proposes to dismiss workers on economic grounds must summon and consults the works committee or staff delegates and inform the competent authority of the proposed dismissals. The employer should indicate to the staff representatives the economic, financial or technical reasons or the dismissals, the number of workers concerned, the categories of workers affected, the proposed criteria for the order of dismissals, the number or workers employed in the establishment and the provisional timetable for the dismissals. The works committee or, in its absence, the staff delegates must be summoned for consultation twice. The interval at which these two meetings are held varies depending on the number of employees affected. After consultation

\footnotetext{
${ }^{6}$ International Labour Organization (2000). Terminations of employment digest: A legislative review. International Labour Office. Geneva, pp. 144, 153-155, 332-334.

7 International Labour Conference 82 Session 1995 (1995). Protection against Unjustified Dismissal. International Labour Office. Geneva, pp.63. ${ }^{8}$ According to Article 148 of the Code of Labor, the collective dismissal from work will be considered to be the termination of labor relations by the employer or reason that have not to do with the employees, when the number of dismissals rom work within 90 days is at least 10 for the enterprises employing up to 100 employees; 15 for the enterprise employing 100-200 employees; 20 for the enterprises employing 200-300 employees; and 30 for the enterprises employing more than 300 employees.

${ }^{9}$ Law No.7961, dated 12.07.1995 Code of Labor of the Republic of Albania
} 
with the workers committee or staff delegates, the employer defines the criteria for setting the order of dismissals. These criteria must take into account family responsibilities, particularly in the case of single parents; length of service in the establishment; the situation of employees whose re-entry into the labour market is difficult (disabled persons or elderly employee) as well as skills.

In Germany, for summary dismissal based on repeated employee misconduct, it is necessary, in principle at least, for the employee to be previously notified that continued misconduct will result in dismissal. It is also required by law that the notice of dismissal be given within two weeks of the time that the reason for dismissal became known. Where there is a work of staff council, the employer is obliged to consult the council before every case or summary or ordinary dismissal, even though the councils response has no impact on the lawfulness of the dismissal. The council must be notified of: the employees to be dismissed; the type, date and reasons for dismissal; criteria applied or selection; and an examination of possibilities for transfer. For summary dismissals the works council has a period of three days to agree or declare reservation in writing, otherwise agreement is assumed by law. In cases of ordinary dismissal the response period extends to one week. If the works council declares objection in due time the employer must hand over the written declaration of objection to the dismissed employee simultaneously with the declaration of dismissal. The employee therefore effectively receives a strategic concept of how to fight the dismissal in court. For handicapped persons the employer must first receive prior consent from Central Agency for the Disabled before issuing a notice of dismissal. Termination of vocational training relationships requires the employer to issue a written rather than oral declaration of dismissal.

Establishments normally employing more than 20 employees must follow a special procedure which promotes protection against dismissal. An employer who is planning collective dismissals must inform the works council in writing of the reasons for the planned redundancy, the total number of redundancies envisage and the time-scale or their implementation. The works council should also be given any additional information it ask for. The employer must consult with the council on whether the measures envisaged can be avoided or mitigated and in what manner. The employer must inform the head of the relevant employment office in writing and without delay if discernible changes suggest collective dismissals are likely within the next 12 months. The employer must forward information of the proposed redundancies and may, if the works council agrees, provide personal details of the employees concerned to help the employment service place them in other jobs. Failure to inform the head of the relevant employment office in writing renders the employer liable for all expenses involving retaining or transposition of employees for a period of six months. The employer must prove that the works council has been notified and consulted on the matter. He must draw up a reconciliation of interests plan if the establishment regularly employs 20 or more employees and is undergoing substantial alteration and composition. The plans aim is reconciliation of the employer and workforces viewpoints. As a general rule, the employer must then wait for one month before proceeding with the redundancies, although the employment office itself may extend this period to two months or reduce it under certain circumstances.

In United Kingdom, according to sec.92 of the Employment Rights Act 1996, if the employee has been continuously employed for at least two years, the employer is required upon request to hand over a written statement, explaining the reasons for the dismissal. Outside of this there are no statutory requirements for a certain procedure; however, the courts expect employers to follow their own guidelines for termination where they exist. These procedural guidelines must bear a minimum of fairness. Under common law, failure to follow fair procedures alone may render a dismissal unfair, even though, had the procedure been abided by, it might have been fair to dismiss the employee. If more than 19 employees are affected by the redundancy, the employer must notify the Secretary of State in writing. Failure to do so may result in a fine. A copy of this notification must be sent to each workers representative who is to be consulted on the redundancy. In addition, if more than 19 employees are proposed to be made redundant, employee representatives are to be consulted by the employer. These representatives are to be representatives of an independent trade union or, in the case of the absence of a recognised trade union in the workplace, representatives specially elected by the employees for the purpose of consultation on redundancy. They are to receive specific information on the redundancies from the employer prior to the consultation. The consultation should begin in good time and, in any event, where the employer is proposing to dismiss 100 or more employees, at least 90 days (otherwise at least 30 days) before the first of the dismissals takes effect. The consultation shall include ways to avoid or reduce the dismissals, and ways to mitigate their consequences. They should be undertaken by the employer with the view to reaching an agreement. If the obligation to consult is not observed, a complaint may be presented to the Industrial Tribunal which may make a protection award to the effect that the employees are to be kept on the payroll for the period set out in the award. The period is to be of such length as the Tribunal determines to be just and equitable in all circumstances having regard to the 
seriousness of employers default ${ }^{10}$.

\section{Period of Notice}

Notice of dismissal or leaving is an institution of long standing, whereby the party wishing to put an end to an employment relationship must warn the other party in advance ${ }^{11}$. According to Article 11 of ILO Convention No.158 (1982), "a worker whose employment is to be terminated shall be entitled to a reasonable period of notice or compensation in lieu thereof, unless he is guilty of serious misconduct, that is, misconduct of such a nature that it would be unreasonable to require the employer to continue his employment during the notice period". The purpose of imposing this obligation on an employer intending to dispense with a worker's service is to prevent the latter from being taken by surprise by immediate termination of employment and to mitigate its detrimental consequences. Given warning, the worker is able to prepare himself to adapt to the situation and look or a new job. The contract of employment is maintained during the period and each party must therefore discharge its obligations ${ }^{12}$.

In Albania, according to Article 142 of Code of Labour, during the probation period, each of the parties may terminate the contract by informing the other party about its decision at least 5 days in advance. After the probation period, to terminate the contract of undefined duration, the parties must respect a notice deadline of one month during the first year of work; of two months for two up to five years of work; of three months or more than five years of work. These time limits may be changed by virtue of written agreement or of a collective agreement. The deadline notice may not be shorter than 2 weeks, when the employee has been working or a period of up to 6 months. The deadline notice is not shorter than one month, when the employee has been working for a period longer than six months. The deadline notice to terminate the contract shall be extended, depending on the case, until the end of the week or of the month. The same rule shall be applied, if the deadline notice is suspended during the period of disability to work, of pregnancy, or of the holiday given by the employer. When one of the parties terminates the contract without respecting the deadline notice, then the termination will be considered as a termination of contract with immediate effect.(see Article 143 of Code of Labour) ${ }^{13}$.

In France, according to sec.L.122-6 of the Labour Code, the notice period for the termination of a contract for an unspecified period is one month, if the employee has worked for between six months and two years and two months after two years service. If the length of service is less than six months, the notice period applied will be governed by local custom and the practice in the occupation. Collective agreement may contain provisions more favourable to works in this regard. An employer who proposes to dismiss workers on economic ground, after notifying the competent administrative authority of the proposed dismissals must respect a notice period at least 30 days if the number of dismissals is less than 100,45 days if the number of dismissals is equal to 100 and less than 250 and 60 days if the number of dismissals is at least 250.

In Germany, according to sec. 622(1) of the Civil Code, the statutory period of notice for both blue-collar and whitecollar workers is four weeks before the $15^{\text {th }}$, or before the end, of the calendar month. According to sec.622 (5) of the Civil Code, contractual regulations providing shorter periods of notice are only lawful for casual employment relationships lasting less than three month. Also, a shorter contractual period can be provided if the employer regularly employs no more than 20 workers (not counting vocational trainees) and does not exceed the notice period of four weeks. However, collective agreements may provide for shorter periods of notice than the statute. In addition, longer periods of notice are provided according to the employees continuous length of service in the same establishment, and after the workers $25^{\text {th }}$ birthday. Dismissals based on these periods have to be pronounced before the end of the calendar month. Referring to sec.622 (3) of the Civil Code, for a probationary employment relationship, the period of notice is only two weeks.

In United Kingdom, according to sec.86, of the Employment Rights Act 1996, if the employee has been continuously employed or one month or more, an employer is required to give notice. The length of notice relates to the length of continuous uninterrupted service. The minimum periods of notice are one week, if continuously employed for less than two years; one week for each year of continuous employment if the period is between two years and less than 12 years and 12 weeks if the period of continuous employment is 12 years or more. In case where the required period of notice has not been observed, the industrial Tribunal may grant payment in lieu of the period that should have been

\footnotetext{
10 International Labour Organization (2000). Termination of employment digests: A legislative review. International Labour Office. Geneva, pp. 144-145, 155-156, 334-335.

$11 \mathrm{Herz}$, E. The Protection of Employees on the Termination of Contracts of Employment International Labour Review, pp. 300.

12 International Labour Conference 82 Session 1995 (1995). Protection against Unjustified Dismissal. International Labour Office. Geneva, pp.89.

13 Law No.7961, dated 12.07.1995 Code of Labor of the Republic of Albania.
} 
observed ${ }^{14}$.

\section{Compensation for Unjustified Dismissal}

It is general principle of law that any right must be exercised within lawful limits. A violation of this principle makes the party at fault responsible for compensating or the prejudice caused to the other party. This rule naturally also applies to the exercise of the right of termination, both as regards the employer and employee. Thus a worker who suffers "arbitrary" and therefore wrongful dismissal acquires a right to compensation ${ }^{15}$.

The remedy of compensation aims at offsetting the financial (and often, but not always, non-financial) effects of unjustified or unfair dismissal. The legal basis of compensation is the harm suffered by the worker from loss of employment, but there are very few laws which impose the obligation of proving the extent of damages suffered by the employee, since damages are often assessed on a set scale calculated under terms established by law. In some countries monetary compensation is the only remedy for unjustified dismissal.

Many laws stipulate that the amount of compensation should be fixed with due consideration to various elements, in particular, the workers length of service, the nature of the employment, the age of the worker and any acquired right, such as pensions, or right to bonus payments. The size of the enterprise is also considered by some statutes in the determination of the amount of compensation to be awarded.

Other criteria, such as supplements to unemployment benefits, are also used to determine compensation levels. Moreover, as noted previously, many countries establish minimum and maximum limits to compensation, while in other legal systems maxima and minima are not specified by statute, but are left to the discretion of the presiding judge or body.

Although lower in some instances, compensation for unjustified dismissal is often calculated using the rate of one month's wages for each year of service, with some countries using higher rates, such as five months or even six months wage per year of service. However, the compensation actually awarded is typically in the vicinity of one year's wages. It is unusual for a court to order an employer to pay compensation higher than general statutory maximum, except in the case of workers enjoying special protection, to whom reference was made earlier, or if otherwise permitted by law ${ }^{16}$.

In Albania according to Article 146 of Labor Code, when the employer has terminated the contract for unreasonable causes is obliged to pay the employee a damage that may amount up to the wage of one year, which is added to the wage he/she must receive during the notice deadline. In the cases of the immediate and unjustified termination of the contract of employment by the employer, the court, after having assessed all the circumstances, will decide to oblige the employer to pay the employee damages that equal to not more than the wage of a working year. Furthermore, the employee will benefit the seniority-related reward, if the employer terminates the contract, and the labor relations have lasted not less than three years. The employee will lose the right to the seniority-related reward, if his/her dismissal from work is of immediate effect and based on reasonable causes. The seniority-related compensation equals at least to the salary of 15 days of work or each complete working year, which is calculated on the bases of the wage existing at the end of the termination of labor relations. If the wage is changeable, the reward will be calculated on the average wage of the preceding year, and it will be indexed. The seniority-related reward will be added to the reward, which is given in the case of the termination of the contract for reasonable causes, or in the case of the termination of contract of immediate effect for no reasonable causes.

When the employer failing to respect the procedure of the collective dismissals from work, is obliged to pay the employee a damage, which equals up to six months of salary, and is added to the wage during the notice deadline, or to the damage compensation, which is received in the case where the deadline fails to be respected as defined by Article 143 of Labor Code ${ }^{17}$.

In France, if the employer fails to observe the notice period, the employee is entitled to compensation in lieu of notice, except in the case of serious fault on the part of the employee. Where en employee is dismissed without the correct procedure being observed, but on well-founded and valid grounds, the court will order the employer to comply with the prescribed procedures and award the employee compensation which must not exceed one months wages. If the grounds for the dismissal are not well-founded and valid, the court may propose the reinstatement of the employee in the

\footnotetext{
14 International Labour Organization (2000). Termination of employment digest: A legislative review. International Labour Office. Geneva, pp. 144145, 155-156, 334-335.

${ }^{15} \mathrm{Herz}$ E, The Protection of Employees on the Termination of Contracts of Employment. International Labour Review, pp.314.

16 International Labour Organization (2000). Terminations of employment digest: A legislative review. International Labour Office. Geneva, pp. 2528.

17 Law No.7961, dated 12.07.1995 Code of Labor of the Republic of Albania.
} 
undertaking. If either of the parties rejects such a proposal, the court will award compensation to the employee not less than the remuneration that the employee during the six months immediately preceding his or her dismissal.

In Germany, jurisdiction on the subject matter of disputes concerning unfair or unjustified dismissal lies with the system of Labour Courts. If the Labour Court rules the employers termination of an employment relationship invalid, it may then dissolve the employment relationship and order the employer to pay appropriate compensation for job loss. The amount of such compensation is decided at the discretion of the court, a sum not exceeding 12 months pay, or 18 months pay in the cases of employees aged over 55. The main criteria applied in fixing the amount are the employees social circumstances (e.g. marital status, dependants, state of health) and prospects in the labour market, the extent to which the dismissal is deemed to be unfair or unjustified, and the employees economic situation.

In United Kingdom, an employee may claim compensation for job loss. However, it should be borne in mind that unless a qualifying period of two years of uninterrupted service is fulfilled, a worker does not qualify for compensation. The amount depends on the length of uninterrupted service between the age of 20 and 65 . For unjustified dismissal, there is a basic award (which is calculated similarly to a redundancy payment to a maximum of, 6,150) on the basis of age and years of service, and a compensatory award. The compensatory award compensates the employee for the loss (of earnings, pension rights, injury to feelings and other non-pecuniary loss) he or she has sustained in consequence of the dismissal in so far as that loss in attributable to action taken by the employer. The maximum compensatory award is, 12000 (1996), but in cases of sex discrimination and race discrimination, there is no limit on the amount of the compensatory award. There is a minimum award in case where:

a) Dismissal is unfair due to reasons of redundancy but no redundancy payment in paid because the employee accepted or unreasonably refused alternative employment (minimum award of two weeks pay mast be ordered;

b) Dismissal is unfair on the grounds of health and safety activities in accordance with previsions of sec.100 of the Employment Rights Act 1996 (compensation shall not be less than 2,770 ;

c) The employee is dismissed for union membership, union-related activities or not being a member of a union (minimum basic award is, 2,700.

If the dismissed employee seeks but does not obtain an order or re-employment/re-engagement, he or she shall be paid an additional special award not exceeding, 27,500. Damages may be sought in the civil courts as well as the Industrial Tribunal. Damages may be awarded for loss opportunity provided by the contract or for mental distress, anxiety and illness caused by the loss ${ }^{18}$.

\section{Concluding Remarks}

The procedure of employment contract termination have a particularly importance to protect employees in their professional life against any unjustified termination of employment. The existing of these instruments provides for the employees guarantees such as that dismissals must be based on valid reasons, the right of employee to be heard prior to a period of notice, procedures to appeal against termination, the right to a period of notice etc.

This article draws attention to the importance of such procedures in both Albanian and some industrialized countries of EU Member States. Indication of the importance of such procedures in Albania is the fact that this procedure shall be applied even in the case of an immediate termination of contract. This procedure establishes the principle that the employee, before his employment is terminated, must have an opportunity to defend himself, for this reason he/she must be informed in writing before the meeting. This meeting is to allow the employee to be heard by the employer and to express his point of view. At the same time the employer is required to give reasons concerning the decision planned to be taken. These procedures ensure that any decision to terminate employment is protected by dialogue and reflection between the parties. If the employment is to be terminated, the employee shall be entitled to a reasonable period of notice. Finally, if the termination is unjustified, in accordance with the national law, the employer shall be ordered to payment of adequate compensation.

Our analysis of procedure contract termination may conclude with the remark that Albanian legal system in dismissal procedures is in full compliance with the legislation of the most industrialized country of EU Member States. Dismissal procedures in Albania are ensured with a good legislation which provides the procedure of employment contract termination, notice to terminate the contract of employment, damages or compensation for unfair or unjustified dismissal etc.

18 International Labour Organization (2000). Terminations of employment digest: A legislative review. International Labour Office. Geneva, pp. $146,157-158,336-337$. 
No doubt that, the existence of such procedures has given more stability to the contract of employment in Albania.

\section{References}

Albanian Constitution.

Albanian Supreme Court, Decision No.19, dated 15.11.2007.

Arrigo Gianni, Casale Giuseppe (2005). Glossary on labour law and industrial relations (with special reference to the European Union).International Labour Office. Geneva.

European Commission, Directorate General Employment, Social Affairs and Equal Opportunities (2006). Termination of Employment Relationships, Legal Situation in the Member States of the European Union.

Herz, E. The Protection of Employees on the Termination of Contracts of Employment. International Labour Review.

ILO's Termination of Employment Convention No.158.

International Labour Conference 82 Session 1995 (1995). Protection against Unjustified Dismissal. International Labour Office. Geneva. International Labour Organization (2000). Terminations of employment digest: A legislative review. International Labour Office. Geneva.

International Labour Organization, (2011). Tripartite Meeting of Experts to Examine the Termination of Employment Convention, 1982 (No.158), and the Termination of Employment Recommendation, 1982 (No.166), Final report. Geneva.

Law No.7961, dated 12.07.1995 Code of Labor of the Republic of Albania.

Termination of Employment Recommendation, 1982 (No.166). 